\title{
The Relationship between Military Expenditure and Certain Growth and Development Related Variables in Transition Economies: A Panel Data Analysis
}

\author{
Sotirios K. Bellos \\ Correspondence: Sotirios K. Bellos, University of Sheffield International Faculty - City College, Business and \\ Economics Department, National Bank of Greece, Greece.
}

Received: June 29, 2017

doi:10.11114/aef.v4i5.2517
Accepted: August 4, $2017 \quad$ Available online: August 9, 2017

URL: https://doi.org/10.11114/aef.v4i5.2517

\begin{abstract}
The paper examines the relation between military expenditure and three growth and development related variables (GDP growth, GDP per capita and Industry Value Added) in 31 transition economies during the 1989-2014 period. The empirical results reflect a positive association between military expenditure and the examined growth and development variables. The causality analysis shows though that the causality direction runs from the examined growth and development related variables towards military expenditure in all cases. This in turn reveals a common tendency in the studied economies, which is related to the tensions and developments in the wider studied area.
\end{abstract}

JEL Classification Numbers: H50, H56

Keywords: transition economies, transition, military expenditure, economic growth, GDP per capita, industry value added

\section{Introduction}

In the last decade of the $20^{\text {th }}$ century the transition countries abandoned the central planning system and entered an adjustment process towards the open market economic system. This adjustment involved tight fiscal policies and radical government expense reduction, including defense related ones.

In addition to the transition process, due to the global economic crisis that followed, all government expenditure forms, including military ones had to be drastically reduced - if not eliminated - on the grounds that their contribution to growth and development was questionable.

The counter-argument to these policies states that military expenditure contributes both to growth and provision of safety, despite the widely held view that its impact is "mean". In addition today's multiple regional tensions dictate a continuous alertness and readiness.

The present paper aims to study this contradictory association of military expenditure with certain growth and development related variables in the transition economies taking into consideration several differentiating parameters. The literature on transition economies and the relation among their military expenditure and growth related variables is limited - to the knowledge of the author - and this article aims at enriching it.

The structure of the paper is as follows: Part 2 contains literature review, part 3 structures the empirical model and analysis, part 4 describes the empirical tools employed and part 5 presents the empirical results. Certain aspects of the results are discussed in part 6 and the paper concludes with part 7.

\section{Literature Review}

The relevant literature can be categorized into three strands the first two of which focus on military expenditure's positive and negative economic impact respectively while the third one adopts a "non impact" approach. Apart from these main strands, the literature also contains several studies referring to special aspects of the defense-growth/development liaison.

The "positive impact" strand contains the study of Bruce Mc Donald and Robert Eger (2010) - focused on 15 ex-Soviet Union States - suggesting the presence of positive externalities in the private sector through military expenditure, the studies of Benoit (1972, 1973, and 1978) who strongly advocated the positive impact of defense expenditure on 
developing countries - on the basis of a Keynesian approach as a government expenditure multiplier - and those of Benoit's followers (Kennedy, 1974; Aben, 1981; Chan, 1985; Dixon and Moon, 1986; Atesoglu and Mueller, 1990; Richards, 1991).

The "negative impact" strand contains Ball's criticism (1983) to Benoit and his challenging views. In the same strand also belong the supporters of the view that military expenditure deteriorates employment (Szymanski, 1973; De Grasse, 1983), crowds out private investments (Dunne et al, 2003; Deger and Smith, 1983; Lim ,1983; Dunne and Vougas, 1999) and results in sovereign debt piling up (Brzoska, 1983; Ahmed, 2012; Alami, 2002; Dunne, 2003; Looney and Frederiksen, 1986; Alexander, 2012; Agostino et al, 2012; Gunluk-Senesen and Sezgin; 2002; Paleologou, 2013) while leaving other public sectors - such as education and health- underdeveloped (Deger, 1981).

The "non-impact" strand of the literature contains the studies of Verner (1983), Landau (1993) and Alexander (1995) focused on Latin America, the Developing world and OECD respectively- together with the studies of Heo (2000) and Ohanian (1997) focused on US. Dunne and Smith (1990) also belong in this category corroborating the insignificant impact of military expenditure mostly on employment.

As mentioned above, the literature also contains studies examining special catalyzing parameters of the defense-growth liaison, such as natural resources (Chun, 2010; Frederiksen and Looney, 1983), the existence of a vertically integrated defense industry (Atesoglu and Mueller, 1990; Haveman et al, 1991), conflicts and sovereign threats (Yang et al, 2011; Aizenmann and Glick, 2003, 2006; Landau, 1993; Maizels and Nissanke, 1986; Chletsos and Kollias, 1995; Antonakis, 2002; Kollias et al, 2004) while also geopolitical ambitions (Malizard and Droff, 2014).

Finally, the literature in the field contains research focusing on large economies - which are significant global playerssuch as China and Russia. The studies in the relation between growth and defense expenditure in Russia are remarkably limited $^{1}$. However, in the case of China, the situation is improved as the literature contains studies indicating the parallel routes of economic growth and military spending (Chen, 2009; Chen \& Feffer, 2009) as well as causality liaisons running from economic growth to military spending and inequality (Chang et al, 2013; Meng et al, 2013). Dimitraki and Menla Ali (2013), who studied the case of China between 1952 and 2010, showed that it is economic strength reflected in GDP that drives military expenditure. The same authors in another study (Menla Ali and Dimitraki, 2014) - again for China's military expenditure - indicated that military spending changes affect growth negatively in conditions of slower growth and higher variance. However, when the prevailing conditions substantially improve, the impact of military expenditure on growth becomes positive following the classic Keynesian multiplier effect.

\section{Empirical Model and Analysis}

Based on the relevant literature and the basic growth theories regarding capital and labor specialization (Harrod, 1939; Domar, 1946; Solow, 1956), the empirical model developed in this paper is the following:

\section{GDPgrowth/GDPpc/INDVALUEit $=$ constant + a STEEL PRODUCTIONit + b SCHOOL ENROLLMENTit $+c$ MILITARY EXPENDITURE it + d EUMEMBERSHIPit + e GLOBAL CRISIS TIME DUMMYt +}

\subsection{Independent Variables}

The right-hand part of the empirical model includes, apart from Military spending which is the main focus of the study, a series of control variables. Steel Production accounts for capital amount and capital basis 2 for the development of industrial and military complex ${ }^{3}$ and strategic importance (Frederiksen and Looney, 1983; Chun, 2010), while also for resource abundance. Tertiary School Enrolment reflects the human capital level. EU membership incorporates geo-economic orientation (Maizels and Nissanke, 1986) and commitment towards higher development levels and economic growth (Barbone and Zalduendo, 1996; Rapacki and Prochniak, 2009). Finally, the Crisis time dummy embodies the 2008 global financial crisis in the form of a time dummy variable.

\footnotetext{
${ }^{1}$ Zatsepin (2007) refers as one of the basic feature of Russia's military expenditure its potentially full secrecy, despite the officially announced transparency policies in the military economy.

2 Initially, Capital Formation was employed, in order to be closer to the theoretical growth model. However, the particular variable was remarkably highly correlated to Military Expenditure (with a correlation over 90\%) and caused serious multicollinearity problems to the empirical results. The Steel Production was significantly associated to Capital Formation and at the same time did not suffer from high correlation with Military Expenditure.

${ }^{3}$ It is interesting to remind that the primary form of today's EU was formed by Steel and Coal producing countries (European Coal and Steel Community - ECSC) on the basis that these are the two elements which are needed to develop a sophisticated industry and military complex
} 


\subsection{Dependent Variables (DEPVAR)}

The left-hand side, apart from economic growth displayed by the GDP growth rate, includes GDP pc accounting for economic development and Industry Value Added for Industrial enhancement.

The variables and the descriptive statistics are presented in the Appendix A (Tables 1 and 2)

\subsection{The Use of Sub-samples}

Certain authors (Antonakis, 2002; Alexander, 1995) referring to the conflicting results of various studies in the field have highlighted the implicit assumption of structural similarity of the sample economies as an essential problem. In order to capture the "structural differences", the analysis adopted the use of sub-samples which included economies sharing common features such as the existence of integrated military industry4, military confrontations5, as well as geographical location6. The Sub-samples are presented in Table 3 (in the Appendix).

\section{Data and Econometric Methodology}

\subsection{Data}

There are 31 countries in the sample (see Appendix - A) and the time period examined is $1989-2014$.

\subsection{Panel Data Method}

The relevant empirical literature demonstrates the use of a variety of methods such as Granger causality (Chen, 1993; Chang et al, 2001), co-integration methods (Masih et al, 1997; Pradhan, 2010) and OLS (Bing-Fu and Liming, 2006). Menla Ali and Dimitraki (2014) consider nonlinearities important, as these are highly associated with fiscal policy variables such as government expenditure. This strand's empirical literature also includes Mc Donald and Eger (2010), Aizenman and Glick (2006), Kalaitzidakis and Tzouvelekas (2011) as well as Yang et al (2011) among others.

The present analysis employs panel data methodology allowing for a much larger degree of freedom in comparison to cross-sectional or time-series studies and resulting in more accurate regression estimates. This method can address omitted variable bias and heterogeneity problems that often arise in cross-sectional investigations. This is particularly important for the current study because it is highly likely that there will be a number of country-specific factors that cannot be directly incorporated into the regression equations. Lastly, panel data has greater capacity for capturing the complexity of social behavior than the cross-section or time-series analysis.

The Hausman test was performed in all regressions for the selection of Random Effects or the Fixed Effects method (it is displayed in the Results Tables, Appendix B). Potential heteroskedasticity problems were resolved by the use of the Newey-West Heteroskedasticity and Autocorrelation Consistent Standard Errors. All variables are in natural logarithmic form and stationarity was tested by using the Levin, Lin and Chu and the Philips Perron methods with a Newey West bandwidth selection. The results confirmed the stationarity of the variables.

The descriptive statistics are displayed in table 2 and the correlation matrix in Table 4 (Appendix A). The annual mean of economic growth in the examined countries is $3.19 \%$ and the corresponding value for military expenditure is USD 7.2 billion. All variables exhibit strong excess kurtosis and skewness and the Jarque - Bera test statistics show that normality is rejected at the $1 \%$ level of significance for all variables. All correlation rates are less than 0.7 and in general the $\mathrm{R} 2$ of the regressions can be characterized as satisfactory (above 0.5 in most of the examined samples).

\subsection{Causality Analysis}

Granger Causality analysis was applied in all significant relationships between Military Expenditure and the dependent variables following similar studies (Cappelen et al , 1984; Chowdbury, 1991; Joerding, 1986, Kusi, 1994). The Granger

\footnotetext{
${ }^{4}$ Usually the presence of a "vertical" industrial complex, due to its size and state of the art technology generates considerable spill-over effects in the domestic industry $(\mathrm{R}+\mathrm{D}$, specialization), while also exporting opportunities designating a positive impact on economic performance (Atesoglu and Mueler, 1990). Beyond that, countries with integrated military industries usually feel vigorous enough to pursue their own geopolitical ambitions, influencing by this way their neighbouring countries military needs and expenditures

${ }^{5}$ War and war like situations have demographic and economic consequences whose duration depend on an economy's development level (Kugler et al, 2012).

${ }^{6}$ The analysis separated the economies of Central and Southeastern Europe from the ex- Soviet Union members. The first ones belong in their majority to EU and those that do not, look forward to becoming EU members, while the second ones are in their majority members of the Commonwealth of Independent States (CIS) a rather "slow paced" group but with promising economic performance (Kurmanalieva and Fedorov, 2011) that in general maintain close links with Russia
} 
Causality runs regression of the following form:

$y_{t}=\mathrm{a}_{0}+\mathrm{a}_{1} y_{t-1}+\ldots+\mathrm{a}_{m} y_{t-m}+\mathrm{b}_{1} x_{t-1}+\ldots+\mathrm{b}_{m} x_{t-\mathrm{m}}+\mathrm{e}_{t}$

$x_{t}=\mathrm{a}_{0}+\mathrm{a}_{1} x_{t-1}+\ldots+\mathrm{a}_{\mathrm{m}} x_{t-m}+\mathrm{b}_{1} y_{t-} l+\ldots+\mathrm{b}_{\mathrm{m}} y_{t-m}+u_{t}$

for all significant associations $\left(x_{t}\right.$ and $\left.y_{t}\right)$ found in the panel data analysis. The reported F-statistics are the Wald statistics for the test of the following joint hypothesis:

$\mathrm{b}_{1}=\mathrm{b}_{2}=\ldots .=0$

The lag length was determined by applying the Akaike Information Criteria (AIC).

\subsection{Missing Observations}

Missing observations is a common problem in transition studies (Mc Donald and Eger, 2010). These are due to a) the examined economies' nature and the previous regime policies either not to keep records or even not to disclose data, and b) the small number of observations in certain sub-samples (e.g. the China - Russia one). Both of them dictate the approach to the results with a certain degree of caution.

\subsection{Empirical Results}

The panel data analysis results are given in tables 5 - 11 (Appendix B). Below we comment on each one of the independent variables starting with the military expenditure variable.

Military Expenditure (\% GDP) bears a positive and significant sign towards GDP growth in three of the sub-samples (W/o China and Russia, Armed Conflict Countries and Ex-Soviet Countries). In the rest four samples (Full, Russia-China, No Conflict Countries, Ex-Soviet), there is no significance between the two variables. In the case of GDP pc and Industry Value added, military expenditure demonstrates a permanent positive association with both dependent variables.

Steel Production demonstrates insignificance in relation with GDP growth in most of the samples. The only case in which it appears to have a positive and significant association is the sample of China and Russia. When GDP pc and Industry Value Added are examined the association with steel production is positive and significant in the majority of the examined subsamples.

The EU dummy is insignificantly associated with GDP growth bearing a negative sign. It demonstrates a positive and significant association when examined with GDP pc in most of the sub-samples (except in the full sample). When Industry Value Added is examined, significance appears only in the non-conflict countries. In general the rest it is not significant. Overall the EU membership appears to have a positive association only with the economic development variable

The Global Crisis Time Dummy, as expected, is negatively associated with GDP growth in the majority of the sub-samples. In the case of GDP pc, a uniform positive and strongly significant association is met. This paradoxical association could be attributed to the fact that the global economic crisis hit the core western economies harder than the transition economies (due to their sophisticated/developed but equally highly vulnerable financial systems) (Shostya, 2014), providing them by this way with a sort of competitive advantage both in terms of economic development and industrial enhancement.

\subsection{Causality Analysis Results}

The Causality Analysis results between military expenditure and the selected dependent variables are displayed in tables 8-14 in Appendix C.

According to the results, there is a persisting causality pattern in all cases of military expenditure significance. In all samples, the causality direction runs from the examined dependent variable towards military expenditure. This indicates a significant tendency to channel the positive economic potential towards military expenditure.

\section{Discussion}

The causality analysis showed that in the entirety of the examined samples there is a clear tendency for the economic prosperity (in terms of economic growth, development and industrial enhancement) to be directed to military expenditure. These results confirm somehow Dimitraki and Menla Ali (2013) as well as Furuoka et al (2014) for their findings on China as they have also shown that it is the development of the Chinese economy that "feeds" military expenditure. In all cases, the adoption of a policy that directs the "product" of a country's economic "fertility" towards increased military spending cannot but be an indication that this country either pursues strengthening of its geopolitical presence or participates in an arms rivalry (Wolfson, 1985, 1989), in order to face potential threats. Due to Russia and China's pivotal role in the examined region which spreads almost across the entire Eurasia, but also to the geopolitical tensions within this or neighboring areas, this distinctive feature has certain implications in determining the military 
expenditure trend of the rest of the transition economies as well. And this can be displayed graphically.

Using data from SIPRI (Stockholm International Peace Research Institute, 2015) the following graphs display military expenditure for the main transition economies groups.

Graph 1 displays military expenditure in China and Russia, where it is clear that both of them follow an upward and particularly "impressive" trend. The involvement of both of these countries in several "hot" areas of the World (e.g Middle East, Pacific Ocean, Africa) and the consequent need for military power in order to perform these "power projections" is displayed in Graph 1.

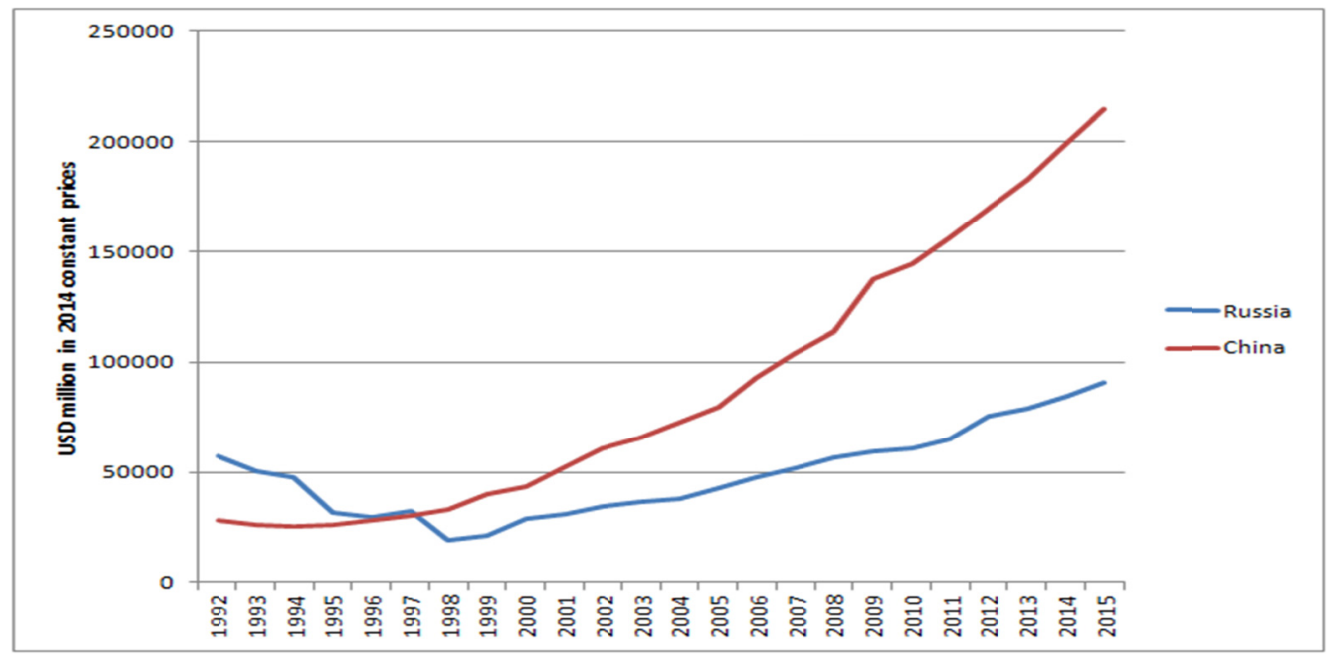

Graph 1. Military Expenditure in China and Russia

(Source: SIPRI Military Expenditure Database 2015, http://milexdata.sipri.org

Graph 2 displays military expenditure in the ex-Soviet Union transition economies (excluding Russia). It is obvious that military expenditure also follows an upward trend in the majority of these countries, probably following military expenditure patterns in their neighboring superpowers, while also tensions in nearby areas. In the same graph it is also interesting to trace military expenditure for countries that experienced a military conflict like Georgia (the figure increased up to 2008, the year of the conflict) and recently Ukraine (sharply increasing from 2000 onwards).

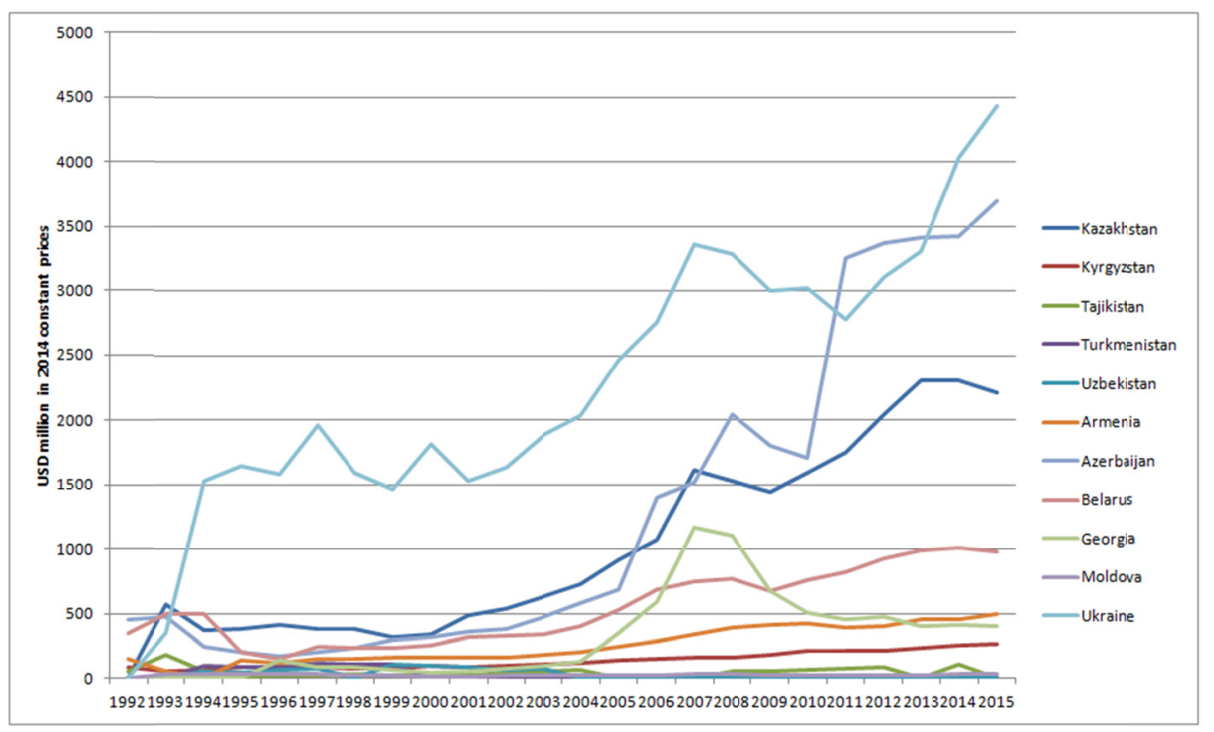

Graph 2. Military Expenditure in the Ex-Soviet Transition Economies(excl. Russia)

(Source: SIPRI Military Expenditure Database 2012, http://milexdata.sipri.org)

Graph 3 displays military expenditure in the Central and Southeastern European transition economies (including the 
Baltic countries due to the fact that they are already EU members). The majority of them follow a declining trend ${ }^{7}$. An exception to that is Poland, Romania and the Baltic countries, which also follow an increasing military expenditure trend, probably influenced by the anxiety in their neighboring countries and regions. These countries are displayed separately in Graphs 3 and 4 below:

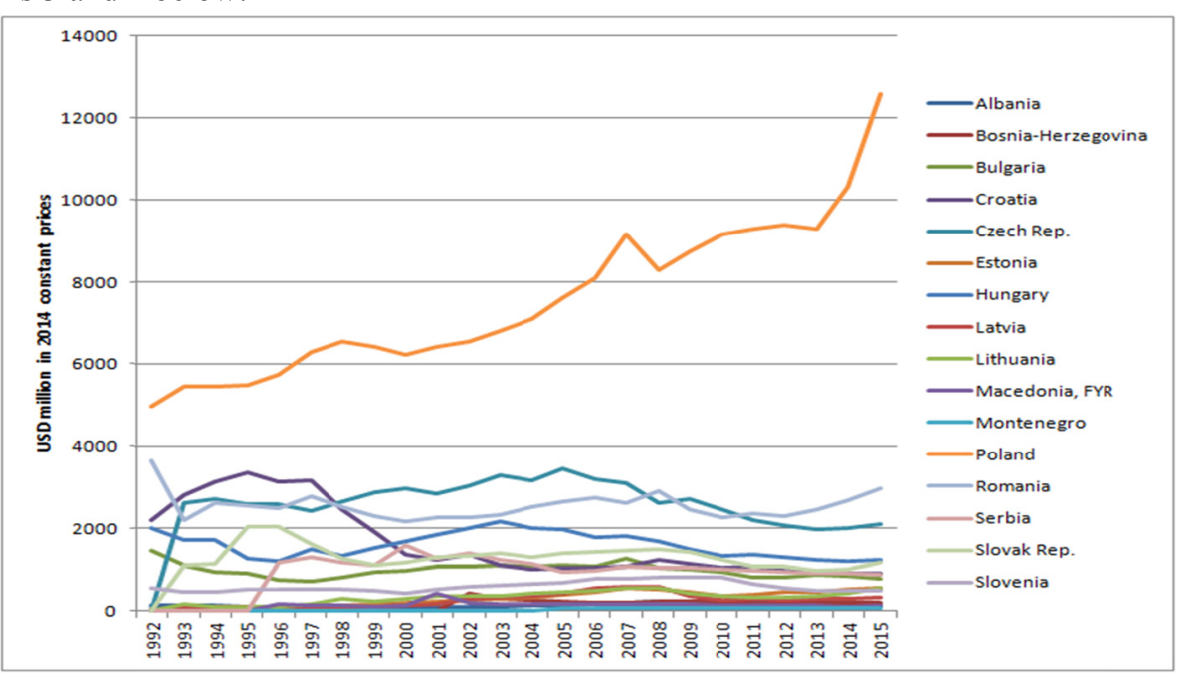

Graph 3. Military Expenditure in Central and Southeastern European Transition Economies

(Source: SIPRI Military Expenditure Database 2015, http://milexdata.sipri.org)

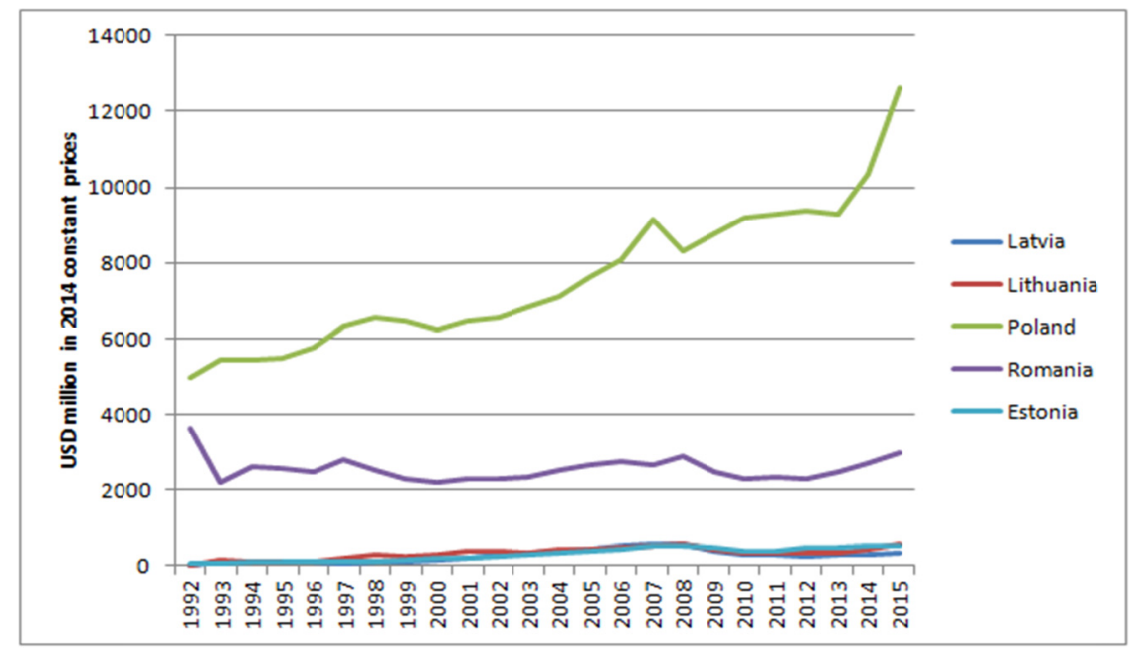

Graph 4. Military Expenditure in Central and Southeastern European Transition Economies neighboring Russia

(Source: SIPRI Military Expenditure Database 2015, http://milexdata.sipri.org)

\section{Conclusions}

The paper has attempted to assess the relation between military expenditure, GDP growth, GDP pc and Industry Value added in 31 transition economies between 1989 and 2011. In general, the empirical findings show that military expenditure in the majority of the studied economies has a significant positive association with the examined dependent variables (strong with GDP pc and Industry Value Added and rather weak with GDP growth). However, this is not a verification of that strand of literature that claims the positive impact of military expenditure on economic performance. The causality analysis performed shows that the causality direction runs from the examined dependent variables (GDP growth, GDP per capita and Industry Value Added) towards Military Expenditure. This in turn reflects the special conditions prevailing in the transition economies, especially those closer to Russia and China, where the geopolitical anxiety and turmoil drags the neighboring economies to increased arms procurements, consuming by this way a significant share of their economic potential.

7 This significant decline of military spending together with $\mathrm{R}+\mathrm{D}$ expenses and troops reduction is also verified by the report of Berteau et al (2015) for CSIS on the European Defense Trends, which states that its causes are the lethargic rates of economic growth in Europe and the tight austerity policies imposed after the global economic crisis. 


\section{References}

Aben, J. (1981). Desarmament, Activite et Emploi, Defence Nationale, May.

Agostino, G., Dunne, J. P., \& Pieroni, L. (2012). Corruption, Military Spending and Growth, Defense and Peace Economics, 236, 591-604. https://doi.org/10.1080/10242694.2012.663579

Ahmed, A. D. (2012). Debt-Burden, military spending and growth in Sub-Saharan Africa: A dynamic panel data analysis, Defence and Peace Economics, 235, 485-506. https://doi.org/10.1080/10242694.2011.627163

Aizenmann, J., \& Glick, R. (2003). Military Expenditure, threats, and growth, NBER Working Paper 9618.

Aizenmann, J., \& Glick, R. (2006). Military Expenditure, threats, and growth, Journal of International Trade \& Economic Development, 152, 129-155. https://doi.org/10.1080/09638190600689095

Alami, R. (2002). Military Debt: Perspectives from the Experience of Arab Countries, Defense and Peace Economics, 131, 13-30. https://doi.org/10.1080/10242690210964

Alexander, W. R. J. (1995). Defence Spending: Burden or Growth - Promoting?, Defence and Peace Economics, 62, 13-25. https://doi.org/10.1080/10430719508404809

Alexander, W. R. J. (2012). The Defence-Debt nexus: Evidence from the high income members of NATO, Defence and Peace Economics, 242, 133-145.

Ali, M. F., \& Dimitraki, O. (2014). Military Spending and Economic Growth in China: A Regime - Switching Analysis, Applied Economics, 4628, 3408-3420. https://doi.org/10.1080/00036846.2014.929626

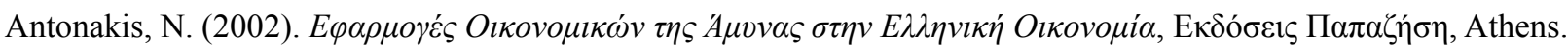

Atesoglu, H. S., \& Mueller, M. J. (1990). Defense Spending and Economic Growth, Defence Economics, 21, 19-27.

Ball, N. (1983). Defense and Development: A Critique of the Benoit study, Economic Development and Cultural Change, 31 April, 507-524. https://doi.org/10.1086/451339

Barbone, L., \& Zalduendo, J. (1996). EU Accession and Economic Growth. The Challenge for Central and Eastern European Countries, World Bank.

Benoit, E. (1972). Growth effects of defense in developing countries, International Development Review, 141, 2-10.

Benoit, E. (1973). Defense and Economic Growth in Developing Countries, Lexington: Lexington Books.

Benoit, E. (1978). Growth and defense in developing countries, Economic Development and Cultural Change, 26 January, 271-280. https://doi.org/10.1086/451015

Berteau, D., Cipoletti, T. J., Sanders, G., Doherty, M., \& Fanlo, A. A. (2015). European Defense Trends: Briefing Update, Center for Strategic and International Studies, National Security Program on Industry and Resources

Brzoska, M. (1983). The Military Related External Debt of Third World Countries, Journal of Peace Research, 203, 271-277. https://doi.org/10.1177/002234338302000308

Cappelen, A., Gleditsch, N. P., \& Bjerkholt, O. O. (1984). Military spending and economic growth in the OECD countries, Journal of Peace Research, 214, 827-838. https://doi.org/10.1177/002234338402100404

Chan, S. (1985). The Impact of Defense Spending on Economic Performance: A Survey of Evidence and Problems, Orbis, 293, 403-434.

Chang, T., Fang, W., \& Wen, L. F. (2001). Defense spending, economic growth and temporal causality: evidence from Taiwan and Mainland China, 1952-1995, Applied Economics, 33, 1289-1299. https://doi.org/10.1080/00036840122529

Chang, T., Lee, C. C., Hung, K., \& Lee, K. H. (2013). Does Military Spending Really Matter for Economic Growth in China and G7 countries: The Roles of Dependency and Heterogeneity, Defence and Peace Economics, 252, 177-191. https://doi.org/10.1080/10242694.2013.763460

Chen, A. (2009). Thirty years of Chinese Reform - Transition from Planned Economy to Market Economy, Asian Social Science, 53, 52-56. https://doi.org/10.5539/ass.v5n3p52

Chen, B. F., \& Zhao, L. M. (2006). The determinants of China's defense expenditure before and after transition, Conflict Management and Peace Science, 23, 227-44. https://doi.org/10.1080/07388940600837730

Chen, C. H. (1993). Causality between defense spending and economic growth: The case of Mainland China, Journal of Economic Studies, 20, 37-43. https://doi.org/10.1108/01443589310048145

Chen, S., \& Feffer, J. (2009). China’s Military Spending: Soft Rise of Hard Threat?, Asian Perspective, 334, 47-67. 
Chletsos, M., \& Kollias, C. (1995). Defense Spending and growth in Greece 1974-1990: some preliminary econometric results, Applied Economics, 27, 883-890. https://doi.org/10.1080/00036849500000042

Chowdbury, A. R. (1991). A Causal Analysis of Defense Spending and Economic Growth, Journal of Conflict Resolution, 351, 73-113.

Chun, C. K. (2010). Do Oil Exports Fuel Defense Spending?, Strategic Studies Institute, Carlisle.

De Grasse, R. W. (1983). Military Expansion, Economic Decline, M.E Sharpe Inc, Armonk, NY.

Deger, S. (1981). Human Resources, Government Education Expenditure and the Military Burden in Less Developed Countries, London Birkbeck College Discussion Paper, No 109.

Deger, S., \& Smith, S. (1983). Military Expenditure and growth in less developed countries, Journal of Conflict Resolution, 282, 335-353. https://doi.org/10.1177/0022002783027002006

Dimitraki, O., \& Menla, A. F. (2013). The Long-run Causal Relationship between Military Expenditure and Economic Growth in China: Revisited, Defence and Peace Economics. https://doi.org/10.1080/10242694.2013.810024

Dixon, W., \& Moon, B. (1986). The Military Burden and Basic Human Needs, Journal of Conflict Resolution, 30, 660-684. https://doi.org/10.1177/0022002786030004004

Domar, E. (1946). Capital Expansion, Rate of Growth and Employment, Econometrica 142, 137-147. https://doi.org/10.2307/1905364

Dunne, J. P. (2003). Military Expenditure and Debt in Small Industrialized Economies: A Panel Analysis, Defense and Peace Economics, 152, 125-132.

Dunne, J. P., \& Smith, R. (1990). Military Expenditure and Unemployment in the OECD, Defence Economics, 1, 57-74. https://doi.org/10.1080/10430719008404650

Dunne, J. P., \& Vougas, D. (1999). Military spending and economic growth in South Africa, Journal of Conflict Resolution, 434, 521-537. https://doi.org/10.1177/0022002799043004006

Dunne, J. P., Nikolaidou, E., \& Mylonidis, N. (2003). The demand for military spending in the peripheral economies of Europe, Defence and Peace Economics, 146, 447-460. https://doi.org/10.1080/1024269032000085215

Frederiksen, P. C., \& Looney, R. E. (1983). Defense Expenditures and Economic Growth in Developing Countries, Armed Forces and Society, 9, 633-645. https://doi.org/10.1177/0095327X8300900406

Furuoka, F., Mikio, O., \& Karim, M. A. (2014). Military Expenditure and Economic Development in China: An Empirical Enquiry, Defence and Peace Economics. https://doi.org/10.1080/10242694.2014.898383

Gleditsch, N. P. P., Wallensteen, M., Eriksson, M., Sollenberg, \& Strand, H. (2002). Armed Conflict 1946-2001: A New Dataset, Journal of Peace Research, 395, 615-637. https://doi.org/10.1177/0022343302039005007

Gunluk, S. G., \& Sezgin, S. (2002). Turkey's defence expenditures and debt burden, Paper presented at the 6th Middlesex Conference on Economics and Security, June 2002, London.

Harrod, R. F. (1939). An Essay in Dynamic Theory, The Economic Journal, 49(193), 14-33.

Haveman, J. D., Deardorff, A. V., \& Stern, R. M. (1991). Some Economic Effects of Unilateral and Multilateral Reductions in Military Expenditures in the Major Industrialized and Developing Countries, Research Seminar in International Economics, Seminar Discussion Paper No 270.

Heo, U. (2000). The Defence - Growth Nexus in the United States Revised, American Politics Quarterly, 281, 110-127. https://doi.org/10.1177/1532673X00028001007

Iimi, A. (2005). Urbanization and Development of Infrastructure in the East Asian Region, Japan Bank for International Cooperation, 10, 88-109.

Joerding, W. (1986). Economic Growth and Defense Spending: Granger Causality in Developing Countries, Journal of Development Economics, 21, 35-40. https://doi.org/10.1016/0304-3878(86)90037-4

Kalaitzidakis, P., \& Tzouvelekas, V. (2011). Military spending and the growth-maximizing allocation of public capital: a cross-country empirical analysis, Economic Inquiry, 49, 1029-1041.

https://doi.org/10.1111/j.1465-7295.2009.00242.x

Kennedy, G. (1974). The Military in the Third World, London: Duckworth.

Kollias, C., Manolas, G., \& Paleologou, S. Z. (2004). Defense Expenditure and economic growth in the European Union: A causality analysis, Journal of Policy Modeling, 265, 553-569.

https://doi.org/10.1016/j.jpolmod.2004.03.013 
Kugler, T., Kang, K. K., Kugler, J., \& Rabinowitz, M. A. (2012). Demographic and Economic Consequences of Conflict, International Studies Quarterly, 1-12. https://doi.org/10.1111/isqu.12002

Kurmanalieva, E., \& Fedorov, K. (2011). CIS Countries: Primary Macroeconomic Indicators, Eurasian Development Bank, Data and Reviews.

Kusi, N. K. (1994). Economic Growth and defense spending in developing countries: A causal analysis, Journal of Conflict Resolution, 381, 152-159. https://doi.org/10.1177/0022002794038001009

Landau, D. (1993). The Economic Impact of Military Expenditures, The World Bank, Policy Research Working Papers, WPS 1138

Lim, D. (1983). Another look at growth and defense in less developed countries, Economic Development and Cultural Change, 312, 377-384. https://doi.org/10.1086/451326

Looney, R. E., \& Frederiksen, P. C. (1986). Defense Expenditure, External Public Debt and Growth in Developing Countries, Journal of Peace Research, 234, 329-338. https://doi.org/10.1177/002234338602300403

Maizels, A., \& Nissanke, M. (1986). The Determinants of Military Expenditures in Developing Countries, World Development, 149, 1125-1140. https://doi.org/10.1016/0305-750X(86)90115-4

Malizard, J., \& Droff, J. (2014). Economic versus Strategic Constraint: The asymmetric behavior of defense spending in France, Document de travail ART-Dev 2014-09.

Masih, A. M. M., Masih, R., \& Hasan, M. S. (1997). New evidence from an alternative methodological approach to the defence spending-economic growth causality issue in the case of Mainland China, Journal of Economic Studies, 24, 123- 140. https://doi.org/10.1108/01443589710167347

McDonald, B. D., \& Eger, R. (2010). The Defense-Growth Relationship: An Economic Investigation into Post-Soviet States, Peace Economics, Peace Science and Public Policy, 161, Article 5, 1-26.

Meng, B., Lucyshyn, W., \& Li, X. (2013). Defence Expenditure and Income Inequality: Evidence on Co-Integration and Causality for China, Defence and Peace Economics.

Ohanian, L. E. (1997). The Macroeconomic Effects of War Finance in the United States: World War II and the Korean War, American Economic Review, 871, 23-40.

Paleologou, S. M. (2013). A Dynamic Panel Data Model for analyzing the relationship between military expenditure and government debt in the EU, Defence and Peace Economics, 245, 419-428. https://doi.org/10.1080/10242694.2012.717204

Pradhan, R. P. (2010). Defence spending and economic growth in China, India, Nepal and Pakistan: Evidence from Cointegrated Panel Analysis, International Journal of Economics and Finance, 12, 65-74.

Rapacki, R., \& Prochniak, M. (2009). The EU Enlargement and Economic Growth in the CEE New Member Countries, European Commission Economic Papers, EP 367.

Richards, P. J. (1991). Disarmament and Employment, Defence Economics, 2, $295-312$. https://doi.org/10.1080/10430719108404704

Shostya, A. (2014). The Effect of the Global Financial Crisis on Transition Economies, Atlantic Economic Journal,433, 317-332. https://doi.org/10.1007/s11293-014-9418-2

SIPRI. (2012). Military Expenditure Database, 2012, http://milexdata.sipri.org

Solow, R. M. (1956). A Contribution to the Theory of Economic Growth, Quarterly Journal of Economics, 70(1), 65-94. https://doi.org/10.2307/1884513

Szymanski, A. (1973). Military Spending and Economic Stagnation, American Journal of Sociology, July edition

Themnér, L., \& Wallensteen, P. (2013). Armed Conflict, 1946-2012, Journal of Peace Research, 504. https://doi.org/10.1177/0022343313494396

UCDP/PRIO. (2013). UCDP/PRIO Armed Conflict Dataset Codebook, Centre for Study of the Civil Wars, International Peace Research Institute, 4-2013.

Verner, J. G. (1983). Budgetary trade-offs between education and defense in Latin America: A research note, Journal of Developing Areas, 181.

Wolfson, M. (1985). Notes on economic warfare, Conflict Management and Peace Science, 82, 1-20. https://doi.org/10.1177/073889428500800201

Wolfson, M. (1989). Foundations of a theory of economic warfare and arms control, Conflict Management and Peace 
Science, 102, 47-75. https://doi.org/10.1177/073889428901000203

World Bank. (2013). World Development Indicators Database, World Bank, Washington, D.C.

Yang, A. J. F., Trunbull, W. N., Yang, C. W., \& Huang, B. H. (2011). On the relationship between Military Expendiure, Threat and Economic Growth: A nonlinear Approach, Defense and Peace Economics, 224, 449-457. https://doi.org/10.1080/10242694.2010.497723

Zatsepin, V. (2007). Russian Military Expenditures: What's Behind the Curtain?, The Economics of Peace and Security, 21, 51-61.

\section{Appendix A}

\section{Participating Countries}

Albania, Armenia, Azerbaijan, Belarus, Bosnia, Bulgaria, China, Croatia, Czech Republic, Estonia, FYROM, Georgia, Hungary, Kazakhstan, Kyrgyzstan, Latvia, Lithuania, Moldova, Mongolia, Montenegro, Poland, Romania, Russia, Serbia, Slovakia, Slovenia, Tajikistan, Turkmenistan, Ukraine, Uzbekistan, Vietnam

\section{Time Period}

The time period examined: 1989 - 2011

Transition period: 1989-2003, Post Transition Period: 2004-2011

Conflict Countries: Armenia, Azerbaijan, Bosnia, Croatia, Serbia, Russia, Georgia, Tajikistan

Table 1. Dependent and Independent variables

\begin{tabular}{|c|c|c|c|}
\hline $\mathbf{N r}$ & NAME & DESCRIPTION & SOURCE \\
\hline \multicolumn{4}{|c|}{ DEPENDENT VARIABLES } \\
\hline 1 & GDP (\%growth) & Economic Growth & $\begin{array}{l}\text { World Development } \\
\text { Indicators 2015 }\end{array}$ \\
\hline 2 & GDP per capita & GDP divided over population. Indicator of Economic Development & $\begin{array}{l}\text { World Development } \\
\text { Indicators 2015 }\end{array}$ \\
\hline 3 & $\begin{array}{l}\text { Industry } \\
\text { Added }\end{array}$ & $\begin{array}{l}\text { According to the WDI definition "Industry corresponds to ISIC divisions } \\
10-45 \text { and includes manufacturing (ISIC divisions 15-37). It comprises value } \\
\text { added in mining, manufacturing (also reported as a separate subgroup), } \\
\text { construction, electricity, water, and gas. Value added is the net output of a } \\
\text { sector after adding up all outputs and subtracting intermediate inputs" }\end{array}$ & $\begin{array}{l}\text { World Development } \\
\text { Indicators } 2015\end{array}$ \\
\hline \multicolumn{4}{|c|}{ INDEPENDENT VARIABLES } \\
\hline 1 & $\begin{array}{l}\text { TERTIARY } \\
\text { SCHOOL } \\
\text { ENROLLMENT (\%) }\end{array}$ & $\begin{array}{l}\text { According to WDI definitions "Gross enrollment ratio is the ratio of total } \\
\text { enrollment, regardless of age, to the population of the age group that } \\
\text { officially corresponds to the level of education shown. Tertiary education, } \\
\text { whether or not to an advanced research qualification, normally requires, as a } \\
\text { minimum condition of admission, the successful completion of education at } \\
\text { the secondary level" }\end{array}$ & $\begin{array}{l}\text { World Development } \\
\text { Indicators } 2015\end{array}$ \\
\hline 2 & $\begin{array}{l}\text { MILITARY } \\
\text { EXPENDITURE }\end{array}$ & Military Expenditure for each country in constant 2014 USD millions & $\begin{array}{ll}\text { SIPRI } & 2015 \\
\text { MILITARY } & \\
\text { EXPENDITURE } & \\
\text { DATABASE } & \\
\end{array}$ \\
\hline 3 & $\begin{array}{l}\text { STEEL } \\
\text { PRODUCTION }\end{array}$ & Annual production of steel in thousands of ktons & $\begin{array}{lr}\text { World } & \text { Steel } \\
\text { Association } & \text { Database } \\
2015 & \\
\end{array}$ \\
\hline 5 & EU & Membership in EU (0 No membership - 1 Membership) & Dummy Variable \\
\hline 6 & TIME DUMMY & $\begin{array}{l}\text { Year after the initiation of the Global Financial Crisis }(0-\text { year before } 2008 \\
-1 \text { year after 2008) }\end{array}$ & Dummy Variable \\
\hline 7 & $\varepsilon_{\text {it }}$ & Error Term & \\
\hline
\end{tabular}


Table 2. Descriptive Statistics of the used variables

\begin{tabular}{|c|c|c|c|c|c|c|}
\hline & GDPGROWTH & GDPPC & \begin{tabular}{|l} 
INDUSTRY VALUE \\
ADDED
\end{tabular} & STEEL PRODUCTION & \begin{tabular}{|l|} 
SCHOOL \\
ENROLLMENT
\end{tabular} & \begin{tabular}{|l|} 
MIL. \\
EXPENDITURE
\end{tabular} \\
\hline Mean & 3.192484 & 4103.793 & 56400000000 & 20954.86 & 36.78343 & 7190.046 \\
\hline Median & 4.282799 & 2677.487 & 6000000000 & 1020.500 & 33.22220 & 598.0699 \\
\hline Maximum & 88.95766 & 20988.24 & 2620000000000 & 822698.0 & 91.02977 & 343617.3 \\
\hline Minimum & -44.90000 & 205.6124 & 237000000 & 1.000000 & 1.531780 & 13.86399 \\
\hline Std. Dev. & 8.277598 & 4120.780 & 236000000000 & 84015.17 & 20.83104 & 28962.40 \\
\hline Skewness & 0.292028 & 1.549330 & 7.523879 & 6.958467 & 0.561159 & 7.375722 \\
\hline Kurtosis & 22.29614 & 5.022888 & 66.27458 & 56.34567 & 2.475228 & 68.53811 \\
\hline Jarque-Bera & 11817.13 & 447.9006 & 126022.0 & 76492.62 & 47.26465 & 123539.3 \\
\hline Probability & 0.000000 & 0.000000 & 0.000000 & 0.000000 & 0.000000 & 0.000000 \\
\hline Sum & 2429.481 & 3221478. & 40300000000000 & 12.656 .737 & 27182.96 & 4723860. \\
\hline $\begin{array}{|ll|}\begin{array}{l}\text { Sum } \\
\text { Dev. }\end{array} & \text { Sq. } \\
\end{array}$ & 52074.15 & 13300000000 & $3.97 \times 10^{25}$ & 4260000000000 & 320242.1 & 550000000000 \\
\hline Observations & 761 & 785 & 715 & 604 & 739 & 657 \\
\hline
\end{tabular}

Table 3. Subsamples used in the empirical analysis

\begin{tabular}{|c|c|c|c|}
\hline $\mathbf{N r}$ & Differentiating Factor & Sub-sample & Remarks \\
\hline \multirow[t]{2}{*}{1} & \multirow{2}{*}{$\begin{array}{l}\text { Integrated Military } \\
\text { Industry }\end{array}$} & Without Russia China & \\
\hline & & Russia China & \\
\hline \multirow[t]{2}{*}{2} & \multirow{2}{*}{ Military Confrontation } & $\begin{array}{ll}\text { Armed } & \text { Conflict } \\
\text { Countries } & \\
\end{array}$ & \multirow{2}{*}{$\begin{array}{l}\text { The appropriate information was taken from the Uppsala Conflict Data } \\
\text { Program database (UCDP/PRIO, 2013; Gleditsch et al 2002; Themner \& } \\
\text { Wallensteen, 2013), in which the major conflicts are those containing at } \\
\text { least } 1000 \text { battle-related death in a given year }\end{array}$} \\
\hline & & No Conflict Countries & \\
\hline \multirow[t]{2}{*}{3} & \multirow{2}{*}{ Geographical Location } & CEE-SEE countries & \\
\hline & & Ex-Soviet countries & \\
\hline
\end{tabular}

Table 4. Correlation Matrix for the used variables

\begin{tabular}{|l|l|l|l|l|l|l|}
\hline & GDP GROWTH & $\begin{array}{l}\text { STEEL } \\
\text { PRODUCTION }\end{array}$ & $\begin{array}{l}\text { SCHOOL } \\
\text { ENROLLMENT }\end{array}$ & $\begin{array}{l}\text { SIPRI } \\
\text { MILEXP }\end{array}$ & $\begin{array}{l}\text { TIME } \\
\text { DUMMY }\end{array}$ & $\begin{array}{l}\text { EU } \\
\text { DUMMY }\end{array}$ \\
\hline GDP GROWTH & 1.000000 & 0.021182 & -0.068937 & 0.044336 & -0.067167 & -0.030300 \\
\hline STEEL PRODUCTION & 0.021182 & 1.000000 & 0.008114 & 0.669018 & 0.014596 & 0.053607 \\
\hline SCHOOLENROLLMENT & -0.068937 & 0.008114 & 1.000000 & -0.077338 & 0.360145 & 0.382998 \\
\hline LNSIPRIMILEXP & 0.044336 & 0.669018 & -0.077338 & 1.000000 & 0.034381 & 0.061581 \\
\hline TIME DUMMY & -0.067167 & 0.014596 & 0.360145 & 0.034381 & 1.000000 & 0.338398 \\
\hline EU DUMMY & -0.030300 & 0.053607 & 0.382998 & 0.061581 & 0.338398 & 1.000000 \\
\hline
\end{tabular}

\footnotetext{
8 According to UCDP, the countries which in the particular period experienced war conditions for at least one year were: Russia, Armenia, Georgia, Serbia, Azerbaijan, Bosnia, Croatia and Tajikistan
} 


\section{Appendix B}

\section{Panel Data Analysis Results}

Table 5. GDP growth as dependent variable

\begin{tabular}{|c|c|c|c|c|c|c|c|}
\hline \multirow[t]{2}{*}{ Dependent Variable } & \multicolumn{7}{|c|}{ GDP growth (\%) } \\
\hline & Full Sample & $\begin{array}{l}\text { W/O } \\
\text { Russia-China }\end{array}$ & $\begin{array}{l}\text { Russia - } \\
\text { China }\end{array}$ & $\begin{array}{l}\text { Armed } \\
\text { Conflict } \\
\text { Countries }\end{array}$ & $\begin{array}{l}\text { No Conflict } \\
\text { Countries }\end{array}$ & CEE - SEE & Ex-Soviet \\
\hline CONSTANT & $\begin{array}{l}3.42 \\
(2.67)^{* *}\end{array}$ & $\begin{array}{l}3.27 \\
(2.20) * *\end{array}$ & $\begin{array}{l}1.03 \\
(0.57)\end{array}$ & $\begin{array}{l}2.18 \\
(2.89)^{* *}\end{array}$ & $\begin{array}{l}3.31 \\
(2.01)^{* *}\end{array}$ & $\begin{array}{l}2.43 \\
(7.68) * * *\end{array}$ & $\begin{array}{l}2.16 \\
(4.86) * * *\end{array}$ \\
\hline $\begin{array}{l}\text { STEEL } \\
\text { PRODUCTION }\end{array}$ & $\begin{array}{l}-0.03 \\
(-0.21)\end{array}$ & $\begin{array}{l}-0.05 \\
(-0.35)\end{array}$ & $\begin{array}{l}0.56 \\
(2.34)^{* *}\end{array}$ & $\begin{array}{l}-0.03 \\
(-0.76)\end{array}$ & $\begin{array}{l}-0.03 \\
(-0.21)\end{array}$ & $\begin{array}{l}0.03 \\
(1.35)\end{array}$ & $\begin{array}{l}-0.01 \\
(-0.23)\end{array}$ \\
\hline $\begin{array}{ll}\text { SCHOO } & \text { L } \\
\text { ENROLLMENT } & \end{array}$ & $\begin{array}{l}0.06 \\
(2.61)^{* *}\end{array}$ & $\begin{array}{l}0.08 \\
(2.68)^{* *}\end{array}$ & $\begin{array}{l}0.14 \\
(1.14)\end{array}$ & $\begin{array}{l}0.18 \\
(1.07)\end{array}$ & $\begin{array}{l}0.04 \\
(1.32)\end{array}$ & $\begin{array}{l}0.31 \\
(3.92)^{* * *}\end{array}$ & $\begin{array}{l}0.31 \\
(2.57)^{* *}\end{array}$ \\
\hline MILEXP & $\begin{array}{l}0.04 \\
(1.39)\end{array}$ & $\begin{array}{l}0.06 \\
(2.01)^{* *}\end{array}$ & $\begin{array}{l}-0.39 \\
(-0.98)\end{array}$ & $\begin{array}{l}0.15 \\
(3.12) * * *\end{array}$ & $\begin{array}{l}0.01 \\
(1.15)\end{array}$ & $\begin{array}{l}-0.03 \\
(-0.87)\end{array}$ & $\begin{array}{l}0.09 \\
(1.97)^{*}\end{array}$ \\
\hline EU DUMMY & $\begin{array}{l}-0.02 \\
(-0.91)\end{array}$ & $\begin{array}{l}-0.02 \\
(-1.12)\end{array}$ & - & - & $\begin{array}{l}-0.03 \\
(-1.30)\end{array}$ & $\begin{array}{l}-0.11 \\
(-1.17)\end{array}$ & - \\
\hline TIME DUMMY & $\begin{array}{l}-0.07 \\
(-3.89) * * *\end{array}$ & $\begin{array}{l}-0.07 \\
(-4.16)^{* * *}\end{array}$ & $\begin{array}{l}0.18 \\
(1.24)\end{array}$ & $\begin{array}{l}-0.11 \\
(-1.47)\end{array}$ & $\begin{array}{l}-0.05 \\
(-2.18)^{* *}\end{array}$ & $\begin{array}{l}-0.19 \\
(-2.21)^{* *}\end{array}$ & $\begin{array}{l}-0.11 \\
(-1.67)^{*}\end{array}$ \\
\hline $\mathrm{R}^{2}$ & 0.173 & 0.148 & 0.241 & 0.189 & 0.130 & 0.067 & 0.189 \\
\hline $\mathrm{N}$ & 431 & 384 & 47 & 72 & 359 & 258 & 116 \\
\hline Hausman & 21.83 & 22.71 & - & 12.67 & 21.28 & 4.35 & 17.41 \\
\hline Method & $\mathrm{FE}$ & $\mathrm{FE}$ & $\mathrm{FE}$ & $\mathrm{FE}$ & $\mathrm{FE}$ & $\mathrm{RE}$ & $\mathrm{FE}$ \\
\hline
\end{tabular}

Note: t-values are in brackets. "*” shows significance at $10 \%$ level. "**"shows significance at 5\% level and “****shows significance in $1 \%$ level. All variables in log form

Table 6. GDP pc as dependent variable

\begin{tabular}{|c|c|c|c|c|c|c|c|}
\hline \multirow{2}{*}{$\begin{array}{l}\text { Dependent } \\
\text { Variable }\end{array}$} & \multicolumn{7}{|l|}{ GDP pc } \\
\hline & $\begin{array}{l}\text { Full } \\
\text { Sample }\end{array}$ & $\begin{array}{l}\text { W/O } \\
\text { Russia-China }\end{array}$ & $\begin{array}{l}\text { Russia - } \\
\text { China }\end{array}$ & $\begin{array}{l}\text { Armed } \\
\text { Conflict } \\
\text { Countries }\end{array}$ & $\begin{array}{l}\text { No } \\
\text { Conflict } \\
\text { Countries } \\
\end{array}$ & $\begin{array}{l}\text { CEE } \\
\text { SEE }\end{array}$ & Ex-Soviet \\
\hline CONSTANT & $\begin{array}{l}4.96 \\
(2.71)^{* *}\end{array}$ & $\begin{array}{l}5.28 \\
(4.37)^{* * *}\end{array}$ & $\begin{array}{l}3.62 \\
(12.14) * * *\end{array}$ & $\begin{array}{l}3.04 \\
(4.33) * * *\end{array}$ & $\begin{array}{l}5.21 \\
(2.71)^{* *}\end{array}$ & $\begin{array}{l}6.41 \\
(4.42)^{* * *}\end{array}$ & $\begin{array}{l}3.86 \\
(10.84)^{* * *}\end{array}$ \\
\hline $\begin{array}{l}\text { STEEL } \\
\text { PRODUCTION }\end{array}$ & $\begin{array}{l}0.03 \\
(1.74)^{*}\end{array}$ & $\begin{array}{l}0.03 \\
(2.28)^{* *}\end{array}$ & $\begin{array}{l}0.10 \\
(1.68)^{*}\end{array}$ & $\begin{array}{l}0.02 \\
(0.99)\end{array}$ & $\begin{array}{l}0.02 \\
(1.63)^{*}\end{array}$ & $\begin{array}{l}0.03 \\
(2.66)^{* *}\end{array}$ & $\begin{array}{l}0.07 \\
(1.88)^{*}\end{array}$ \\
\hline $\begin{array}{lr}\text { SCHOO L L } \\
\text { ENROLLMENT }\end{array}$ & $\begin{array}{l}0.34 \\
(13.14)^{* * *}\end{array}$ & $\begin{array}{l}0.30 \\
(13.17)^{* * *}\end{array}$ & $\begin{array}{l}0.46 \\
(8.32)^{* * *}\end{array}$ & $\begin{array}{l}0.69 \\
(5.87)^{* * *}\end{array}$ & $\begin{array}{l}0.36 \\
(14.5)^{* * *}\end{array}$ & $\begin{array}{l}0.35 \\
(14.8)^{* * *}\end{array}$ & $\begin{array}{l}0.38 \\
(3.94)^{* * *}\end{array}$ \\
\hline MILEXP & $\begin{array}{l}0.24 \\
(8.58) * * *\end{array}$ & $\begin{array}{l}0.23 \\
(13.74) * * *\end{array}$ & $\begin{array}{l}0.13 \\
(3.22)^{* * *}\end{array}$ & $\begin{array}{l}0.32 \\
(6.41)^{* * *}\end{array}$ & $\begin{array}{l}0.22 \\
(6.39)^{* * *}\end{array}$ & $\begin{array}{l}0.11 \\
(4.65)^{* * *}\end{array}$ & $\begin{array}{l}0.25 \\
(7.58)^{* * *}\end{array}$ \\
\hline EU DUMMY & $\begin{array}{l}0.03 \\
(1.35) \\
\end{array}$ & $\begin{array}{l}0.05 \\
(2.00)^{* *}\end{array}$ & - & - & $\begin{array}{l}0.04 \\
(1.80)^{*}\end{array}$ & $\begin{array}{l}0.09 \\
(5.15)^{* * *}\end{array}$ & - \\
\hline TIME DUMMY & $\begin{array}{l}0.20 \\
(11.55)^{* * *}\end{array}$ & $\begin{array}{l}0.20 \\
(10.01)^{* * *}\end{array}$ & $\begin{array}{l}0.20 \\
(7.13)^{* * *}\end{array}$ & $\begin{array}{l}0.18 \\
(2.83)^{* *}\end{array}$ & $\begin{array}{l}0.17 \\
(10.25)^{* * *}\end{array}$ & $\begin{array}{l}0.12 \\
(6.97)^{* * *}\end{array}$ & $\begin{array}{l}0.27 \\
(5.31)^{* * *}\end{array}$ \\
\hline $\mathrm{R}^{2}$ & 0.881 & 0.891 & 0.889 & 0.794 & 0.886 & 0.878 & 0.811 \\
\hline $\mathrm{N}$ & 439 & 391 & 48 & 74 & 365 & 265 & 117 \\
\hline Hausman & 63.24 & 41.67 & - & 3.41 & 52.73 & 30.79 & 3.89 \\
\hline Method & $\mathrm{FE}$ & FE & $\mathrm{FE}$ & $\mathrm{RE}$ & FE & FE & $\mathrm{RE}$ \\
\hline
\end{tabular}

Note: t-values are in brackets. "*” shows significance at $10 \%$ level. "**”shows significance at $5 \%$ level and “***»shows significance in $1 \%$ level. All variables in log form 
Table 7. Industry Value Added as dependent variable

\begin{tabular}{|c|c|c|c|c|c|c|c|}
\hline \multirow{2}{*}{$\begin{array}{l}\text { Dependent } \\
\text { Variable }\end{array}$} & \multicolumn{7}{|c|}{ INDUSTRY VALUE ADDED } \\
\hline & Full Sample & $\begin{array}{l}\text { W/O } \\
\text { Russia-China }\end{array}$ & $\begin{array}{l}\text { Russia } \quad- \\
\text { China }\end{array}$ & $\begin{array}{l}\text { Armed } \\
\text { Conflict } \\
\text { Countries }\end{array}$ & $\begin{array}{l}\text { No Conflict } \\
\text { Countries }\end{array}$ & CEE - SEE & Ex-Soviet \\
\hline CONSTANT & $\begin{array}{l}1.84 \\
(7.07)^{* * *}\end{array}$ & $\begin{array}{l}1.84 \\
(9.32)^{* * *}\end{array}$ & $\begin{array}{l}1.98 \\
(3.95)^{* * *}\end{array}$ & $\begin{array}{l}1.70 \\
(2.23)^{* *}\end{array}$ & $\begin{array}{l}1.75 \\
(6.71)^{* * *}\end{array}$ & $\begin{array}{l}1.66 \\
(6.89)^{* * *}\end{array}$ & $\begin{array}{l}1.79 \\
(3.63)^{* * *}\end{array}$ \\
\hline $\begin{array}{l}\text { STEEL } \\
\text { PRODUCTION }\end{array}$ & $\begin{array}{l}0.13 \\
(4.75)^{* * *}\end{array}$ & $\begin{array}{l}0.13 \\
(6.65)^{* * * *}\end{array}$ & $\begin{array}{l}0.31 \\
(3.65)^{* * *}\end{array}$ & $\begin{array}{l}0.03 \\
(0.89)\end{array}$ & $\begin{array}{l}0.20 \\
(6.47)^{* * *}\end{array}$ & $\begin{array}{l}0.12 \\
(7.06)^{* * *}\end{array}$ & $\begin{array}{l}0.21 \\
(4.20)^{* * *}\end{array}$ \\
\hline $\begin{array}{l}\text { SCHOO } \\
\text { ENROLLMENT }\end{array}$ & $\begin{array}{l}0.32 \\
(8.37)^{* * *}\end{array}$ & $\begin{array}{l}0.26 \\
(6.71)^{* * *}\end{array}$ & $\begin{array}{l}0.47 \\
(6.34)^{* * *}\end{array}$ & $\begin{array}{l}0.69 \\
(4.15)^{* * *}\end{array}$ & $\begin{array}{l}0.18 \\
(5.41)^{* * * *} \\
\end{array}$ & $\begin{array}{l}0.26 \\
(5.86)^{* * *}\end{array}$ & $\begin{array}{l}0.12 \\
(0.90)\end{array}$ \\
\hline MILEXP & $\begin{array}{l}0.38 \\
(8.01)^{* * *}\end{array}$ & $\begin{array}{l}0.37 \\
(12.95) * * *\end{array}$ & $\begin{array}{l}0.17 \\
(3.29)^{* * *}\end{array}$ & $\begin{array}{l}0.49 \\
(9.93) * * *\end{array}$ & $\begin{array}{l}0.49 \\
(9.72)^{* * *}\end{array}$ & $\begin{array}{l}0.66 \\
(10.35)^{* * *}\end{array}$ & $\begin{array}{l}0.43 \\
(9.12)^{* * *}\end{array}$ \\
\hline EU DUMMY & $\begin{array}{l}-0.05 \\
(-0.15) \\
\end{array}$ & $\begin{array}{l}0.01 \\
(0.30)\end{array}$ & - & - & $\begin{array}{l}0.10 \\
(2.81)^{* *}\end{array}$ & $\begin{array}{l}0.04 \\
(0.87)\end{array}$ & - \\
\hline TIME DUMMY & $\begin{array}{l}0.14 \\
(5.79)^{* * *}\end{array}$ & $\begin{array}{l}0.16 \\
(4.91)^{* * *}\end{array}$ & $\begin{array}{l}0.05 \\
(1.53)\end{array}$ & $\begin{array}{l}0.10 \\
(1.33)\end{array}$ & $\begin{array}{l}0.09 \\
(2.81)^{* *}\end{array}$ & $\begin{array}{l}0.12 \\
(3.02)^{* * *}\end{array}$ & $\begin{array}{l}0.14 \\
(2.04)^{* *}\end{array}$ \\
\hline $\mathrm{R}^{2}$ & 0.887 & 0.867 & 0.879 & 0.887 & 0.768 & 0.729 & 0.776 \\
\hline $\mathrm{N}$ & 425 & 378 & 47 & 72 & 353 & 252 & 116 \\
\hline Hausman & 96.91 & 77.09 & - & 150.1 & 3.92 & 4.52 & 4.01 \\
\hline Method & $\mathrm{FE}$ & $\mathrm{FE}$ & $\mathrm{FE}$ & $\mathrm{FE}$ & $\mathrm{RE}$ & $\mathrm{RE}$ & $\mathrm{RE}$ \\
\hline
\end{tabular}

Note: t-values are in brackets. “*” shows significance at 10\% level. "**”shows significance at 5\% level and “***”shows significance in $1 \%$ level. All variables in log form

\section{Appendix C}

\section{Causality Analysis}

Table 8. Full Sample

\begin{tabular}{|llll|}
\hline Null Hypothesis: & Obs & F-Statistic & Prob. \\
LGDPPC does not Granger Cause LNSIPRIMILEXP & $\mathbf{5 2 9}$ & $\mathbf{1 6 3 . 2 5 5}$ & $\mathbf{0 . 0 0 0 0}$ \\
LNSIPRIMILEXP does not Granger Cause LGDPPC & & 338.174 & 0.0181 \\
LNINDVALADD does not Granger Cause LNSIPRIMILEXP & $\mathbf{5 0 7}$ & $\mathbf{1 4 9 . 0 9 0}$ & $\mathbf{0 . 0 0 0 0}$ \\
LNSIPRIMILEXP does not Granger Cause LNINDVALADD & & 106.408 & 0.3639 \\
\hline
\end{tabular}

Table 9. W/o Russia and China

\begin{tabular}{|c|c|c|c|}
\hline Null Hypothesis: & Obs & F-Statistic & Prob. \\
\hline LNGDPGROWTH does not Granger Cause LNSIPRIMILEXP & 510 & 290.679 & 0.0000 \\
\hline LNSIPRIMILEXP does not Granger Cause LNGDPGROWTH & & 228.634 & 0.1027 \\
\hline LGDPPC does not Granger Cause LNSIPRIMILEXP & 518 & $\mathbf{3 0 7 . 3 3 7}$ & 0.0000 \\
\hline LNSIPRIMILEXP does not Granger Cause LGDPPC & & 0.36039 & 0.6976 \\
\hline LNINDVALADD does not Granger Cause LNSIPRIMILEXP & 495 & 295.142 & 0.0000 \\
\hline LNSIPRIMILEXP does not Granger Cause LNINDVALADD & & 0.31661 & 0.7288 \\
\hline
\end{tabular}

Table 10. Russia - China

\begin{tabular}{|c|c|c|c|}
\hline Null Hypothesis: & Obs & F-Statistic & Prob. \\
\hline LGDPPC does not Granger Cause LNSIPRIMILEXP & 43 & 389.252 & 0.0166 \\
\hline LNSIPRIMILEXP does not Granger Cause LGDPPC & & 0.30230 & 0.8235 \\
\hline LNINDVALADD does not Granger Cause LNSIPRIMILEXP & 43 & 294.633 & 0.0458 \\
\hline LNSIPRIMILEXP does not Granger Cause LNINDVALADD & & 220.655 & 0.1041 \\
\hline
\end{tabular}


Table 11. Conflict

\begin{tabular}{|llll|}
\hline Null Hypothesis: & Obs & F Statistic & Prob. \\
LNGDPGROWTH does not Granger Cause LNSIPRIMILEXP & $\mathbf{1 3 6}$ & $\mathbf{1 8 7 . 3 6 2}$ & $\mathbf{0 . 0 0 0 0}$ \\
LNSIPRIMILEXP does not Granger Cause LNGDPGROWTH & & 132.200 & 0.2701 \\
LGDPPC does not Granger Cause LNSIPRIMILEXP & $\mathbf{1 3 7}$ & $\mathbf{1 6 3 . 1 9 1}$ & $\mathbf{0 . 0 0 0 0}$ \\
LNSIPRIMILEXP does not Granger Cause LGDPPC & & 0.03347 & 0.9671 \\
LNINDVALADD does not Granger Cause LNSIPRIMILEXP & $\mathbf{1 2 6}$ & $\mathbf{1 8 7 . 1 5 3}$ & $\mathbf{0 . 0 0 0 0}$ \\
LNSIPRIMILEXP does not Granger Cause LNINDVALADD & & 0.33851 & 0.7135 \\
\hline
\end{tabular}

Table 12. No Conflict

\begin{tabular}{|llll|}
\hline Null Hypothesis: & Obs & F-Statistic & Prob. \\
LGDPPC does not Granger Cause LNSIPRIMILEXP & $\mathbf{4 2 6}$ & $\mathbf{1 6 4 . 7 7 4}$ & $\mathbf{0 . 0 0 0 0}$ \\
LNSIPRIMILEXP does not Granger Cause LGDPPC & 0.69896 & 0.4977 \\
LNINDVALADD does not Granger Cause LNSIPRIMILEXP & $\mathbf{4 1 4}$ & $\mathbf{2 1 4 . 6 8 7}$ & $\mathbf{0 . 0 0 0 0}$ \\
LNSIPRIMILEXP does not Granger Cause LNINDVALADD & & 0.12090 & 0.8862 \\
\hline
\end{tabular}

Table 13. SEE - CEE

\begin{tabular}{|llll|}
\hline Null Hypothesis: & Obs & F-Statistic & Prob. \\
LGDPPC does not Granger Cause LNSIPRIMILEXP & $\mathbf{2 9 9}$ & $\mathbf{1 4 8 . 4 9 1}$ & $\mathbf{0 . 0 0 0 0}$ \\
LNSIPRIMILEXP does not Granger Cause LGDPPC & 0.29162 & 0.7473 \\
LNINDVALADD does not Granger Cause LNSIPRIMILEXP & $\mathbf{2 7 6}$ & $\mathbf{1 5 1 . 9 0 6}$ & $\mathbf{0 . 0 0 0 0}$ \\
LNSIPRIMILEXP does not Granger Cause LNINDVALADD & & 0.18588 & 0.8305 \\
\hline
\end{tabular}

Table 14. Ex-SOVIET

\begin{tabular}{|llll|}
\hline Null Hypothesis: & Obs & F-Statistic & Prob. \\
LNGDPGROWTH does not Granger Cause LNSIPRIMILEXP & $\mathbf{2 0 2}$ & $\mathbf{1 6 7 . 7 9 7}$ & $\mathbf{0 . 0 0 0 0}$ \\
LNSIPRIMILEXP does not Granger Cause LNGDPGROWTH & & 177.699 & 0.1718 \\
LGDPPC does not Granger Cause LNSIPRIMILEXP & $\mathbf{2 0 2}$ & $\mathbf{1 6 0 . 7 5 5}$ & $\mathbf{0 . 0 0 0 0}$ \\
LNSIPRIMILEXP does not Granger Cause LGDPPC & & 0.78608 & 0.4571 \\
LNINDVALADD does not Granger Cause LNSIPRIMILEXP & $\mathbf{1 8 8}$ & $\mathbf{8 5 5 . 2 3 5}$ & $\mathbf{0 . 0 0 0 0}$ \\
LNSIPRIMILEXP does not Granger Cause LNINDVALADD & & 133.895 & 0.2632 \\
\hline
\end{tabular}

\section{Copyrights}

Copyright for this article is retained by the author(s), with first publication rights granted to the journal.

This is an open-access article distributed under the terms and conditions of the Creative Commons Attribution license which permits unrestricted use, distribution, and reproduction in any medium, provided the original work is properly cited. 